\title{
CHARACTERISTICS OF DYE-SENSITIZED SOLAR CELLS WITH CARBON NANOMATERIALS
}

\author{
ZNAČILNOSTI NA FIKSIRANO BARVO OBČUTLJIVIH SOLARNIH \\ CELIC Z OGLJIKOVIMI NANOMATERIALI
}

\author{
Leszek Adam Dobrzański, Agnieszka Mucha, Marzena Prokopiuk vel Prokopowicz, \\ Marek Szindler, Aleksandra Drygała, Krzysztof Lukaszkowicz \\ Silesian University of Technology, Konarskiego St. 18A, 44-100, Gliwice, Poland \\ krzysztof.lukaszkowicz@polsl.pl \\ Prejem rokopisa - received: 2014-07-30; sprejem za objavo - accepted for publication: 2015-09-21
}

doi: $10.17222 /$ mit.2014.134

\begin{abstract}
Dye-sensitized photovoltaic cells consisting of a layered structure have been developed for 20 years and they are a basis for the new development trend of photovoltaics. One of the examined aspects of their application is building-integrated photovoltaics Dye-sensitized photovoltaic cells (DSSCs) were developed by Michael Grätzel and Brian O'Regan in 1991 and have been intensively examined ever since. Because of their low production costs, easy transfer, the relatively high efficiency of the photon conversion to the current and an easy production technology, dye-sensitized cells might represent an alternative to silicon cells. Basically, a dye-sensitized photovoltaic cell consists of five elements: a mechanical base covered with a layer of transparent conductive oxides (TCOs), a semiconductor film, e.g., $\mathrm{TiO}_{2}$, dye absorbed on the semiconductor's surface, an electrolyte including a redox carrier, and a counter electrode suitable to regenerate a redox carrier, e.g., platinum. As part of this work we produced dye-sensitized solar cells. First, the glass with transparent conductive oxides was thoroughly cleaned. Then, the glass with TCO was coated with a layer of $\mathrm{TiO}_{2}$ using the doctor-blade technique, and fired in a furnace at $450{ }^{\circ} \mathrm{C}$. The plate prepared in this way was then sensitized in a ruthenium-based dye. The counter electrode was obtained by applying it on the glass with TCO carbon nanomaterials, including graphite, carbon black and carbon nanotubes. The photo-anode and the counter electrode were combined and between them was injected the redox electrolyte. This paper provides an analysis of the microstructure and electrical properties of nanostructural coatings with the carbon nano-element of the integrated dye-sensitized photovoltaic cells. Keywords: dye-sensitized solar cell, carbon elements, counter electrode
\end{abstract}

$\mathrm{Na}$ fiksirano barvo občutljive fotovoltaične celice sestojijo iz plastovite strukture in so zadnjih dvajset let tematika razvoja na tem področju, predstavljajo namreč nov razvojni trend v fotovoltaiki. Eden od raziskovanih vidikov njihove uporabe je fotovoltaika, integrirana v zgradbe. Na fiksirano barvo občutljive fotovoltaične celice (DSSC), sta razvila Michael Grätzel in Brian O’Regan leta 1991 in so od tedaj pogost predmet raziskav. Zaradi nizkih stroškov njihove proizvodnje, enostavne prenosljivosti, relativno visoko učinkovite konverzije fotonov v tok in enostavne proizvodnje, so na fiksirano barvo občutljive celice lahko nadomestek silicijevim celicam. V osnovi na fiksirano barvo občutljive fotovoltaične celice sestojijo iz 5 elementov: mehanska podlaga je prekrita s plastjo prosojnih, prevodnih oksidov $\mathrm{TCO}$, polprevodnega sloja, $\mathrm{npr}$. $\mathrm{TiO}_{2}$, fiksne barve absorbirane na površini polprevodnika, elektrolita z vključno redoks nosilcem nasprotna elektroda, ki je sposobna regeneracije redoks nosilca, kot je npr. platina. Kot del tega dela, so bile izdelane na fiksirano barvo občutljive solarne celice. Najprej je bilo steklo s presevnimi prevodnimi oksidi dobro očiščeno. Nato je bilo steklo s TCO, z uporabo tehnike kirurških nožev, prekrito s plastjo $\mathrm{TiO}_{2}$ in žgano v peči pri $450^{\circ} \mathrm{C}$. Tako pripravljena plošča je bila občutljiva za barve na osnovi rutenija. Nasprotna elektroda je bila dobljena z nanosom TCO ogljikovih nanomaterialov, vključno z grafitom, črnim ogljikom in ogljikovimi nanocevkami na steklu. Fotoanoda in nasprotna elektroda sta bili kombinirani in med njiju je bil vbrizgan redoks elektrolit. Članek predstavlja analizo mikrostrukture in električnih lastnosti prevlek z nano strukturo, z ogljikovimi nanoelementi integrirane fotovoltaične celice, občutljive na fiksirano barvo.

Ključne besede: solarna celica, občutljiva na fiksirano barvo, ogljikovi elementi, nasprotna elektroda

\section{INTRODUCTION}

The increasing rate of energy consumption in the world is directly related to the increase in the human population. The progress of civilization is associated with an increase in the demand for energy, and particularly the most useful of its forms - electricity. Nowadays, mankind consumes 13,500 GW of power. The solar power reaching the Earth is $170,000,000 \mathrm{GW}$. If even a part of this energy could be used it could reduce environmental problems involving atmospheric pollution, arising as a result of the excessive use of conventional energy sources. Photovoltaics is an alternative and environmentally friendly technology for electricity produc- tion. Photovoltaic cells (also known as solar cells or PV cells) are used to convert solar energy into electricity, and this phenomenon is called the photovoltaic effect. The main advantage that enhances the development of organic photovoltaics is the potentially several times lower price of energy production per unit cell area than conventional solar cells based on silicon. Other advantages include ${ }^{1-4}$ much better aesthetics compared to silicon solar cells, low toxicity, high transparency, possibility to choose the colour, flexibility, low deadweight, low power loss due to the unfavourable angle of incidence of the sunlight, which is used in BIPV (Building Integrated Photovoltaics), working under reduced radiation (cloudy, darkening), where these cells 


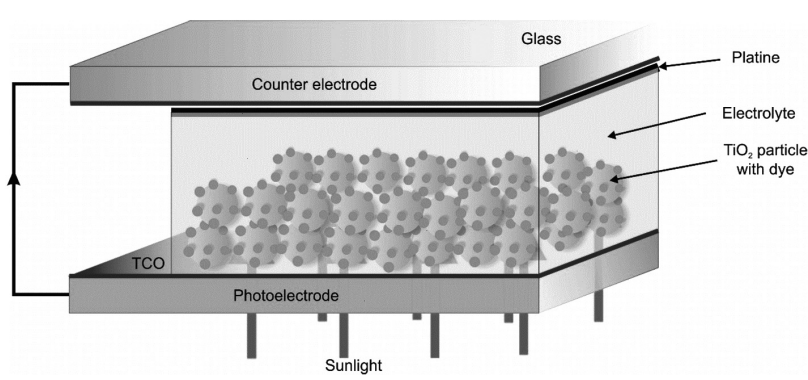

Figure 1: Construction of dye-sensitized solar cell ${ }^{6}$ Slika 1: Zgradba solarne celice občutljive na fiksirano barvo ${ }^{6}$

have a much better performance than silicon solar cells, a low production price due to the use of small amounts of material and the simplicity of production technologies, and the performance is independent of temperature changes in the range of $25-65^{\circ} \mathrm{C}$.

The construction of a dye-sensitized solar cell is based on a layered structure, which consists of two transparent glass plates with a Transparent Conductive Oxide (TCO) on it, placed parallel to each other and spaced about $40 \mu \mathrm{m}$ apart (Figure 1). On one of the plates is applied a nanocrystalline titanium oxide layer coated organometallic photosensitive dye (photosensitizer) this system retrieve in the cell function photo-anode (illuminated anode). On the surface of the second plate glass with TCO is usually nanoplatinum, which is a catalytic layer - this system is in the cell cathode. The space between the plates is filled with an electrolyte containing a redox system $\mathrm{I}^{-} / \mathrm{I}^{3-}$. Each component shows the dependence between many other materials. If at least one element in dye-sensitized solar cells is changed, e.g., the dye, the particle size of the $\mathrm{TiO}_{2}$, the film thickness, or the composition of the electrolyte, the DSSC cell re-



Figure 2: The operating principle of dye-sensitized solar cells ${ }^{6}$ Slika 2: Princip delovanja solarnih celic, občutljivih na fiksirano barvo ${ }^{6}$ quires adjustment to ensure optimal system performance. ${ }^{5,6}$

The operating principle of a dye-sensitized solar cell is shown in Figure 2. The dye and the electrolyte are essential components of the cell.

The task of the counter electrode is to gather electrons flowing from the outer current and to catalyse the reduction of the triiodide ions. Platinum is the most common material used as a counter electrode. Despite the fact that platinum shows a high catalytic activity, its shortage in resources, high costs and corrosion possibility through a triiodide solution, inhibit its application on a large scale in the future. ${ }^{7}$ For this reason, there is a need for research on alternative materials that are characterized by electrochemical activity and chemical stability. So far platinum ${ }^{8}$, carbon, ${ }^{9,10}$ conductive plastics, ${ }^{11}$ $\mathrm{CoS},{ }^{12} \mathrm{WO}_{2},{ }^{13}, \mathrm{Mo}_{2} \mathrm{C}$ and $\mathrm{WC},{ }^{14} \mathrm{TiN},{ }^{15}$ have been used as the counter electrodes. There are many publications about the methods of shaping the surface and structure of materials to improve their properties. ${ }^{16-18}$

Carbon nanotubes conduct electricity. They are almost transparent, flexible and strong, which makes them the ideal material for transparent electrodes for DSSC. The only drawback is that photo-generated charge carriers in the nanotube may recombine with ions in the dye, which reduces the power-conversion efficiency of the solar cell.

In the present work inexpensive and available carbon materials such as carbon black, graphite, and carbon nanotubes have been used as alternative materials to platinum because of their high corrosive resistance, high reactivity for triiodide reduction and low costs. ${ }^{7,9,10,19-25}$ The disadvantages in catalytic activity in comparison to platinum may be compensated for by increasing the active surface of a catalytic layer using the porous structure. $^{7,25}$ Forming high-quality carbon bands on a substrate gives us prospects for using carbon as a counter electrode.

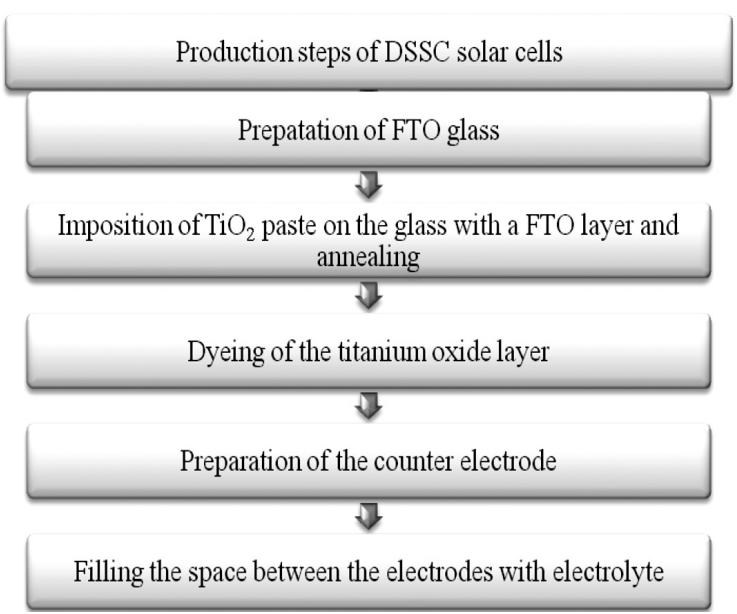

Figure 3: The production steps of dye-sensitized solar cells Slika 3: Proizvodni koraki pri solarnih celicah, občutljivih na fiksirano barvo 


\section{EXPERIMENTAL PROCEDURE}

The production steps for dye-sensitized solar cells were shown in Figure 3. As the counter electrodes we used three carbon materials: carbon black, graphite and carbon nanotube. The dye-sensitized solar cells have the following arrangement of layers (Figure 4):

- FTO glass $/ \mathrm{TiO}_{2} /$ dye/electrolyte/carbon black/FTO glass,

- FTO glass/ $/ \mathrm{TiO}_{2} /$ dye/electrolyte/graphite/FTO glass,

- FTO glass/TiO $/$ /dye/electrolyte/nanotube/FTO glass, where:

FTO glass is glass with a layer of fluorine-doped tin oxide (FTO).

\subsection{Fabrication of the photoanode}

Glass plates with dimensions $30 \mathrm{~mm} \times 30 \mathrm{~mm}$ $(10 \Omega /$ sq.) were used. In order to remove any surface contamination and to degrease, the FTO glasses were dipped and held in an ultrasonic, deionized water, acetone, ethanol and isopropanol. In order to reduce the active surface of the dye-sensitized solar cells the FTO glass was covered with a layer of tape (Figure 5). In order to obtain a $\mathrm{TiO}_{2}$ paste nitric acid with $\mathrm{pH} 3-4$ was mixed with ethanol. ${ }^{26-28}$ To the solution was added titanium oxide nanopowder. This solution was stirred until a uniform paste was obtained. A drop of $\mathrm{TiO}_{2}$ paste was



Figure 4: Schema of DSSC with: a) carbon black, b) graphite, c) carbon nanotube

Slika 4: Shema DSSC z: a) črnim ogljikom, b) grafitom, c) ogljikovimi nanocevkami

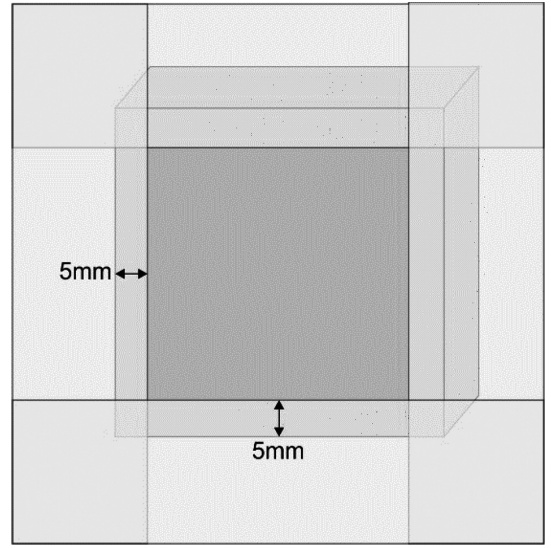

Figure 5: FTO glass covered with a layer of tape

Slika 5: FTO-steklo, prekrito s plastjo traku

applied to the FTO glass and then it was uniformly spread over the glass surface using the doctor-blade technique (Figure 6). After removing the tape, the glass plate with the titanium paste was annealed in a furnace at $450{ }^{\circ} \mathrm{C}$ in air and then air-cooled. In order to sensitize the electrode it was immersed in the dye solution with absolute ethanol for $24 \mathrm{~h}$ at room temperature, without access to light. Once removed, the electrode was washed with ethanol to remove any excess dye and allowed to dry. A glass plate with a layer of titanium oxide, with and without dye, is shown in Figure 7.

\subsection{Fabrication of the counter electrode}

The preparation of the carbon nanotubes' surface layers on the silicon substrates was performed using EasyTube ${ }^{2} 2000$. During the process the default settings were used. EasyTube ${ }^{\circledR} 2000$ is an advanced, turnkey, thermal catalytic chemical vapor deposition CVD process tool for the synthesis of a wide variety of nanostructured materials. The catalyst needed for the CNT growth was a transition metal plus iron, and the catalyst was introduced to the process together with the CNT precursor.

It this case the counter electrodes were prepared by spring carbon nanotubes on the FTO glass. The CNT solution was prepared by direct mixing of the acid highly conductive PEDOT:PSS and applied on the glass surface with FTO. The second electrode that was used for this experiment was the electrode with carbon black. The



Figure 6: Photo-anode preparation

Slika 6: Priprava fotoanode 


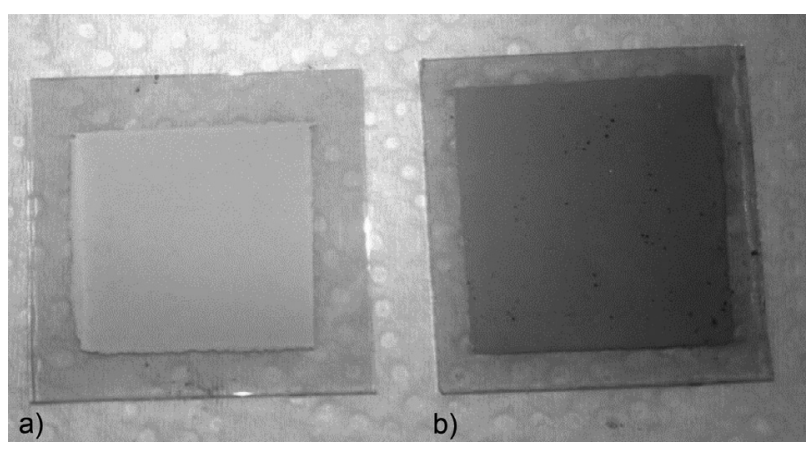

Figure 7: FTO glass with $\mathrm{TiO}_{2}$ layer: a) before dying, b) after dying Slika 7: FTO steklo s plastjo $\mathrm{TiO}_{2}$ : a) pred sušenjem, b) po sušenju

carbon black is cheap in industrial mass production. Ti is also used in printing toners, so we can easily spray it on to FTO glass.

A thin layer of carbon materials, i.e., carbon black (Figure 8a), graphite (Figure 8b), carbon nanotube (Figure 8c), were deposited on the FTO glass that was previously cleared of impurities.

\subsection{Fabrication of the DSSC}

An anode and a cathode were combined with the sealing strip, which simultaneously serves as a separator. Careful electrode bonding is a very important step in the preparation of DSSC cells. It prevents the leakage and evaporation of the electrolyte.

The last step was the placement the electrolyte, which is a solution of iodine and iodide in an organic solvent containing a redox couple $\mathrm{I}^{-} / \mathrm{I}^{3-}$, between the photo-anode and a counter electrode.

\subsection{Measurements}

Because the used carbon elements and titanium oxide consist of nano-metric structural units or single carbon layers, modern research equipment was used. First of all, an Atomic Force Microscope, a High Resolution Transmission Electron Microscope and a Scanning Electron Microscope.
Atomic force microscopy (AFM, XE-100, Park Systems) was used to observe the surface morphology of the $\mathrm{TiO}_{2}$ layer with and without the dye.

The counter electrodes' morphology was observed using the scanning electron microscope (SEM; SUPRA 35, ZEISS).

The High Resolution Transmission Electron Microscope S/TEM (TITAN 80-300, FEI) was used to observe the surface morphology of the carbon nanotubes.

The voltages of the DSSCs were recorded using a multimeter (Meter Link Extech EX845) as a source measure unit, which was connected between the FTO glass and the counter electrode.

\section{RESULTS AND DISCUSSION}

Figure 9 shows the AFM images of the $\mathrm{TiO}_{2}$ layer and the dye-adsorbed $\mathrm{TiO}_{2}$ layer. The size and the dis-



Figure 9: AFM images of the: a) $\mathrm{TiO}_{2}$ layer and b) dye-adsorbed $\mathrm{TiO}_{2}$ layer

Slika 9: AFM-posnetek: a) plast $\mathrm{TiO}_{2}$ in b) s fiksirano barvo adsorbirana plast $\mathrm{TiO}_{2}$

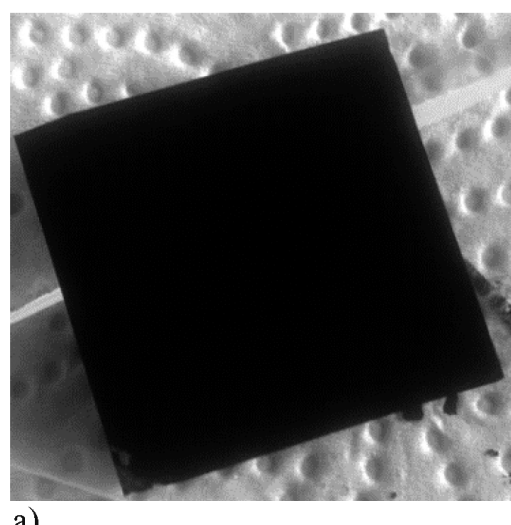

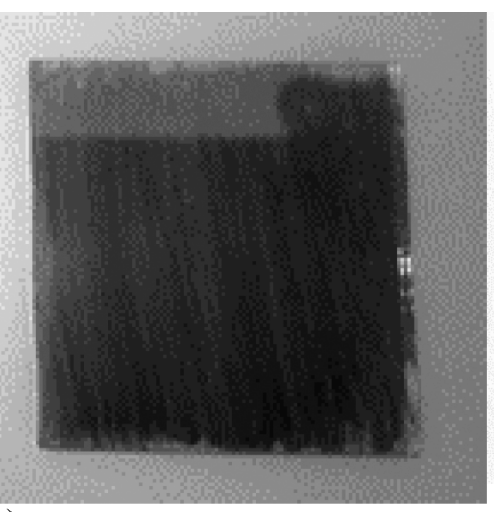

b)

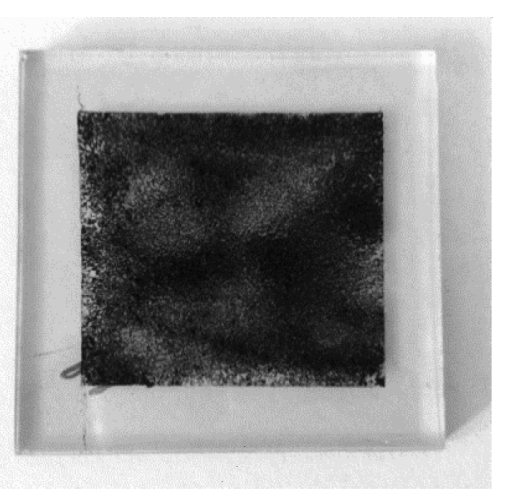

c)

Figure 8: Counter electrode with a layer of: a) carbon black, b) graphite, c) PEDOT: PSS with carbon nanotubes Slika 8: Nasprotna elektroda s plastjo: a) črnega ogljika, b) grafita, c) PEDOT: PSS z ogljikovimi nanocevkami 




Figure 10: SEM image of carbon black Slika 10: SEM-posnetek črnega ogljika

tribution of the particles characterize the dye-absorbed surface of the photo-anode. The SEM images show that $\mathrm{TiO}_{2}$ surface with the absorbed dye is smoother than the surface without the dye.

Figures 10 to $\mathbf{1 2}$ show the SEM surface images of various counter electrodes on the FTO glass. Figure 10 shows the microstructure of the carbon black, where a rectangular atomic arrangement can be observed. Because the fluorine-doped tin oxide film deposited on the glass has a rough surface, in Figure 11 where the graphite is shown, we can also observe the rough pyramid microstructure. Figure 12 shows the microstructure of the carbon nanotubes' electrode, where severely agglomerated CNTs are observable. We can see that the surface with the CNT and the highly conductive PEDOT:PSS has a uniform structure and fewer pores were generated in the structure compared with the microstructure of the carbon black or the graphite.

By adding carbon nanotubes to the electrode it is possible to obtain a larger surface area and therefore a



Figure 11: SEM image of graphite

Slika 11: SEM-posnetek grafita

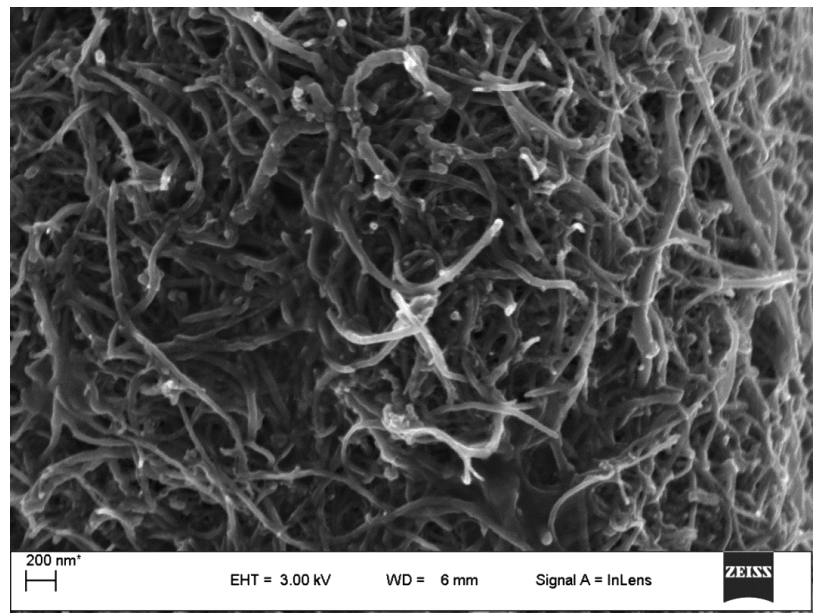

Figure 12: SEM images of carbon nanotubes Slika 12: SEM-posnetek ogljikovih nanocevk

larger contact surface than the graphite and carbon black counter electrode.

Table 1 shows the electrical parameters by means of voltage for the three dye-sensitized solar cells with three different counter electrodes. As was expected after the SEM images, the highest voltage comes from the DSSC with carbon nanotubes as a counter electrode.

Table 1: Electrical properties of the investigated DSSCs

Tabela 1: Električne lastnosti preiskovane DSSC

\begin{tabular}{|l|c|}
\hline \multicolumn{1}{|c|}{ Type of counter electrode } & Voltage $(\mathrm{mV})$ \\
\hline carbon black & 40 \\
\hline graphite & 35 \\
\hline carbon nanotubes & 52 \\
\hline
\end{tabular}

\section{CONCLUSIONS}

In this study, for the purpose of decreasing the cost of dye-sensitized solar cells (DSSCs), we investigated the effect of carbon materials, i.e., carbon nanotubes, graphite and carbon black, added as a counter electrode. Three different low-cost DSSCs (CNT-counter electrode DSSC, carbon black-counter electrode DSSC, graphiteelectrolyte DSSC) were fabricated.

The costly platinum electrode is able to be replaced by the modified counter electrode (using CNTs), with only little change in the efficiency of the cell. The effect of the carbon nanotubes on the performance of the DSSC showed that the DSSC fabricated with the CNT and PEDOT:PSS had the highest photovoltaic performances. These results are attributed to increasing the surface area of the counter electrode.

The conductivity of the carbon black is lower than carbon materials such as the graphite and carbon nanotubes, because those carbon nanotubes have a high conductivity and a large surface area. The literature proves that the carbon nanotubes with PEDOT:PSS layers have a good adhesion, so it can be used on the DSSC 
electrodes. In the future it is planned to perform tests of the adhesion for the products' layers of low-cost DSSCs.

The investigated effect of the CNT counter electrodes on the efficiency of DSSC showed that these kinds of solar cells had the best efficiency for the counter electrodes.

\section{Acknowledgment}

The project was funded by the National Science Centre on the basis of the contract No. DEC-2013/09/B/ ST8/02943.

\section{REFERENCES}

${ }^{1}$ J. Szlachta, S. Chrobak, DSCC cells - colorful future of photovoltaics, Green Energy, 9 (2013), 56-58

${ }^{2}$ B. I. Stiepanow, Fundamentals of chemistry and technology of organic dyes, Scientific and Technical Publishing, Warsaw 1980

${ }^{3}$ J. Godlewski, J. Kosk, M. Makowska, Dye sensitized solar cells, Green Energy, 3 (2008), 28-29

${ }^{4}$ A. Wrobel, J. Wasik, J. Godlewski, Trends in development of organic solar cells, Green Energy, 7-8 (2010), 22-23

${ }^{5}$ K. Siuzdak, Synthesis and properties of non-metals doped titanium dioxide as the active electrode material in visible light, $\mathrm{PhD}$ Thesis, Gdansk University of Technology, Gdansk, 2012

${ }^{6}$ H. Desilvestro, Y. Hebting, M. Khan, D. Milliken, Understanding and successfully applying materials for dye-sensitized solar cells, Materials Matters, 9 (2014) 1, 14-18

${ }^{7}$ S. Xu, Y. Luo, W. Zhong, Investigation of catalytic activity of glassy carbon with controlled crystallinity for counter electrode in dye-sensitized solar cells, Solar Energy, 85 (2011) 11, 2826-2832, doi:10.1016/j.solener.2011.08.014

${ }^{8}$ X. L. He, M. Liu, G. J. Yang, S. Q. Fan, C. J. Li, Correlation between microstructure and property of electroless deposited Pt counter electrodes on plastic substrate for dye-sensitized solar cells, Applied Surface Science, 258 (2011) 4, 1377-1384, doi:10.1016/j.apsusc. 2011.09.070

${ }^{9}$ S. U. Lee, W. S. Choi, B. Hong, A comparative study of dye-sensitized solar cells added carbon nanotubes to electrolyte and counter electrodes, Solar Energy Materials \& Solar Cells, 94 (2010) 4, 680-685, doi:10.1016/j.solmat.2009.11.030

${ }^{10} \mathrm{~K}$. Li, Y. Luo, Z. Yu, M. Deng, D. Li, Q. Meng, Low temperature fabrication of efficient porous carbon counter electrode for dye-sensitized solar cells, Electrochemistry Communications, 11 (2009) 7, 1346-1349, doi:10.1016/j.elecom.2009.04.025

${ }^{11}$ J. Nei de Freitas, C. Longo, A. Flavia Nogueria, M. A. De Paoli, Solar module using dyesensitized solar cells with a polymer electrolyte, Solar Energy Materials \& Solar Cells, 92 (2008) 9, 1110-1114, doi:10.1016/j.solmat.2008.03.022

${ }^{12}$ M. Wang, A. M. Anghel, B. Marsan, N. L. Cevey Ha, N. Pootrakulchote, S. M. Zakeeruddin, M. Grätzel, CoS supersedes Pt as efficient electrocatalyst for triiodide reduction in dyesensitized solar cells, Journal of the American Chemical Society, 131 (2009) 44, 15976-15977, doi:10.1021/ja905970y

${ }^{13}$ M. X. Wu, X. A. Lin, A. Hagfeldt, T. L. Ma, A novel catalyst of $\mathrm{WO}_{2}$ nanorod for the counter electrode of dye-sensitized solar cells, Chem. Commun., 47 (2011), 4535-4537, doi:10.1039/c1cc10638d
${ }^{14}$ M. X. Wu, X. A. Lin, A. Hagfeldt, T. L. Ma, Low-cost molybdenum carbide and tungsten carbide counter electrodes fo rdye-sensitized solar cells, Angewandte Chemie International Edition, 50 (2011) 15, 3520-3524, doi:10.1002/anie.201006635

${ }^{15}$ Q. W. Jiang, G. R. Li, X. P. Gao, Highly ordered TiN nanotube arrays as counter electrodes for dye-sensitized solar cells, Chemical Communications, 44 (2009), 6720-6722, doi:10.1039/b912776c

${ }^{16}$ S. Lesz, R. Szewczyk, D. Szewieczek, A. Bieńkowski, The structure and magnetoelastic properties of the Fe-based amorphous alloy with Hf addition, Journal of Materials Processing Technology, 157-158 (2004), 743-748, doi:10.1016/j.jmatprotec.2004.07.133

${ }^{17}$ K. Lukaszkowicz, L. A. Dobrzański, A. Zarychta, Structure, chemical and phase compositions of coatings deposited by reactive magnetron sputtering onto the brass substrate, Journal of Materials Processing Technology, 157-158 (2004), 380-387, doi:10.1016/ j.jmatprotec.2004.09.059

${ }^{18}$ L. A. Dobrzański, M. Kremzer, K. Golombek, Structure and properties of aluminum matrix composites reinforced by $\mathrm{Al}_{2} \mathrm{O}_{3}$ particles, Materials Science Forum, 591-593 (2008), 188-192, doi:10.4028/ www.scientific.net/MSF.591-593.188

${ }^{19}$ K. Li, Y. Luo, Z. Yu, M. Deng, D. Li, Q. Meng, Low temperature fabrication of efficient porous carbon counter electrode for dye-sensitized solar cells, Electrochemistry Communications, 11 (2009) 7, 1346-1349, doi:10.1016/j.elecom.2009.04.025

${ }^{20} \mathrm{~F}$. Miao, B. Tao, P. K. Chu, Enhancementof the efficiency of dye-sensitized solar cells with highly ordered Pt-decorated nanostructured silicon nanowires based counter electrodes, Electrochimica Acta, 96 (2013), 61-65, doi:10.1016/j.electacta.2013.02.059

${ }^{21}$ A. Kay, M. Grätzel, Low cost photovoltaic modules based on dye sensitized nanocrystalline titanium dioxide and carbon powder, Solar Energy Materials and Solar Cells, 44 (1996) 1, 99-117, doi:10.1016/ 0927-0248(96)00063-3

${ }^{22}$ K. Imoto, K. Takahashi, T. Yamaguchi, T. Komura, J. Nakamura, K. Murata, High-performance carbon counter electrode for dye-sensitized solar cells, Solar Energy Materials and Solar Cells, 79 (2003) 4, 459-469, doi:10.1016/S0927-0248(03)00021-7

${ }^{23}$ Z. Huang, X. Liu, K. Li, D. Li, Y. Luo, H. Li, W. Song, L. Q. Chen, Q. Meng, Application of carbon materials as counter electrodes of dye-sensitized solar cells, Electrochemistry Communications, 9 (2007) 4, 596-598, doi:10.1016/j.elecom.2006.10.028

${ }^{24}$ S. Peng, Y. Wu, P. Zhi, V. Thavasi, G. Mhaisalkar, S. Ramakrishna, Facile fabrication of polypyrrole/funcionalized multiwalled carbon nanotubes composite as counter electrodes in low-cost dye-sensitized solar cells, Journal of Photochemistry and Photobiology A: Chemistry, 223 (2011) 2-3, 97-102, doi:10.1016/j.jphotochem.2011.08.004

${ }^{25} \mathrm{H}$. Anwar, A. E. George, I. G. Hill, Vertically-aligned carbon nanotube counter electrodes for dye-sensitized solar cells, Solar Energy, 88 (2013), 129-136, doi:10.1016/j.solener.2012.11.013

${ }^{26}$ G. P. Smestad, Nanocrystalline Solar Cell Kit, Madison, The Institute for Chemical Education, Madison 2008

${ }^{27}$ A. Hagfeldt, M. Grätzel, Molecular Photovoltaics, Accounts of Chemical Research, 33 (2000) 5, 269-277, doi:10.1021/ar980112j

${ }^{28}$ N. J. Cherepy, G. P. Smestad, M. Grätzel, J. Z. Zhang, Ultrafast Electron Injection: Implications for Photoelectrochemical Cell Utilizing an Anthocyanin Dye-Sensitized $\mathrm{TiO}_{2}$ Nanocrystalline Electrode, Journal of Physical Chemistry B, 101 (1997) 45, 9342-9351, doi:10.1021/jp972197w 